\title{
Substituent effect on spectral and antimicrobial activity of Schiff bases derived from aminobenzoic acids
}

\author{
Felicia N. Ejiah ${ }^{1}$, Tolulope M. Fasina ${ }^{1 *}$, Oluwole B. Familoni ${ }^{1}$, Folashade T. Ogunsola ${ }^{2}$ \\ ${ }^{1}$ Department of Chemistry, University of Lagos, Lagos, Nigeria \\ ${ }^{2}$ Department of Medical Microbiology, College of Medicine, University of Lagos, Lagos, Nigeria \\ Email: "tofefash@yahoo.ca
}

Received 15 August 2013; revised 21 September 2013; accepted 2 October 2013

Copyright (C) 2013 Felicia N. Ejiah et al. This is an open access article distributed under the Creative Commons Attribution License, which permits unrestricted use, distribution, and reproduction in any medium, provided the original work is properly cited.

\begin{abstract}
The dependence of electronic absorption spectra antimicrobial property on the substituent position was investigated using three Schiff bases derived from salicylaldehyde and isomeric aminobenzoic acids in three solvents of different polarities. The absorption maxima in all three solvents exhibited dependence on the position of substituent with the absorption maxima undergoing a red shift as solvent polarity increased. The in vitro antibacterial activity of the compounds against some clinically important bacteria namely $E s$ cherichia coli (ATCC 25922), Pseudomonas aeruginosa (ATCC 27853), Staphylococcus aureus (ATCC 25923), Enterococcus feacalis (ATCC 29212) was determined in $\mathrm{N}, \mathrm{N}$ "-dimethylformamide and 1,4-dioxane using the agar dilution method. The results revealed that the ortho and meta substituted Schiff bases exhibited better antimicrobial activity in the non-polar solvent.
\end{abstract}

Keywords: Schiff Base; Aminobenzoic Acid; Antibacterial Activity; Salicyaldehyde; Electronic Spectra

\section{INTRODUCTION}

Schiff base compounds have been shown to be promising leads for the design of efficient antimicrobial agents as a result of the broad range of biological activities exhibited by these compounds. These compounds and their metal complexes are reported to exhibit antifungal, antibacterial, antimalarial, antiproliferative, anti-inflammatory, antiviral and antipyretic properties [1-3].

The mode of interaction and inhibition effectiveness of Schiff bases with bacteria and fungi is expected to depend on the molecular structure of the compounds. Thus, advances in this field will require analyses of structure

*Corresponding author. activity relationships of Schiff bases along with investigation of the mechanism of action of these compounds [4].

In particular, Schiff bases composed of salicyaldehydes are very promising in the search of new functional materials. They exhibit a variety of biological activities $[5,6]$ as well as show important photochromism where light absorption causes interconversion between enolimine and keto-amine tautomers through intramolecular hydrogen transfer.

As part of our efforts to study structure activity relationship of Schiff bases, we report the effect of substituent position on the electronic spectra and antimicrobial activity of Schiff bases of isomeric aminobenzoic acids with salicylaldehyde.

\section{EXPERIMENTAL}

\subsection{Material and Methods}

All chemicals were obtained commercially from SigmaAldrich Chemicals. The solvents: ethanol, 1,4-dioxane, $\mathrm{N}, \mathrm{N}$ "-dimethylformamide (DMF) and acetonitrile were of spectroscopic grade and used without further purification.

Infra-Red spectra were recorded as $\mathrm{KBr}$ pellets on a Shimadzu FT-IR 157 Spectrophotometer. ${ }^{1}$ H NMR Spectra were obtained using a Bruker $400 \mathrm{MHz}$ spectrometer in $\mathrm{d}^{6}$-dimethysulfoxide (DMSO) solution with tetramethylsilane (TMS) as internal standard. Microanalytical data were determined using a CE-440 Elemental analyser, EAI Exeter Analytical Inc. Melting points were determined with Gallenkamp melting point apparatus.

The electronic spectra of the solution were investigated in various solvents of different polarities: 1,4dioxane, N,N"-dimethylformamide (DMF) and acetonitrile. The electronic spectra were recorded on a T80/T80 UV-VIS spectrophotometer using $1 \mathrm{~cm}$ quartz cell at room temperature immediately after preparing the so- 
lutions in order to obtain the spectra of mainly the enolimine tautomer.

\subsection{Typical Synthesis of a Schiff Base}

Equimolar quantities $(10 \mathrm{mmol})$ of salicylaldehyde and primary amine were dissolved in ethanol $(25 \mathrm{ml})$. Two drops of ethanoic acid was added and the mixture allowed to reflux at $70^{\circ} \mathrm{C}$ for $6 \mathrm{~h}$. The reaction mixture was cooled to room temperature, the precipitate collected by filtration, re-crystallized from ethanol, and dried in a desiccator.

2-(2-hydroxybenzylideneamino) benzoic acid (1). Orange crystalline product, yield $52 \%$, mp: $198^{\circ} \mathrm{C}-199^{\circ} \mathrm{C}$, IR (KBr) v/cm ${ }^{-1}: 3440,1682,1618,1567,1459,919,677$. ${ }^{1} \mathrm{H}$ NMR $\left(\delta\right.$ DMSO-d $\left.{ }_{6}\right): 13.06(\mathrm{~s}, 1 \mathrm{H}, \mathrm{OHC}=\mathrm{O}), 8.95$ (s, $1 \mathrm{H}, \mathrm{HC}=\mathrm{N}) 7.97(\mathrm{~d}, \mathrm{IH}) ; 7.78(\mathrm{~d}, 1 \mathrm{H}) ; 7.74(\mathrm{t}, 1 \mathrm{H}) ; 7.09$ (t, 1H); 7.07 (d, 1H); $7.05(\mathrm{~d}, \mathrm{IH})$.

Anal. Calcd. for $\mathrm{C}_{14} \mathrm{H}_{11} \mathrm{NO}_{3}: \mathrm{C}, 69.70 ; \mathrm{H}, 4.56 ; \mathrm{N}$, 5.80. Found: C, 69.23; H, 4.53; N, 5.77.

3-(2-hydroxybenzylideneamino) benzoic acid (2). Yellow powdery solid, yield $86 \%$, mp: $183^{\circ} \mathrm{C}-184^{\circ} \mathrm{C}$, IR (KBr) $v / \mathrm{cm}^{-1}: 3408,3057,1679,1599,1568,1493,941$ 753. ${ }^{1} \mathrm{H}$ NMR $\left(\delta \mathrm{DMSO}_{6}\right): 12.84(\mathrm{~s}, 1 \mathrm{H}, \mathrm{OHC}=\mathrm{O})$, $9.00(\mathrm{~s}, 1 \mathrm{H}, \mathrm{HC}=\mathrm{N}), 7.92(\mathrm{~s}, \mathrm{IH}) ; 7.91(\mathrm{~d}, 1 \mathrm{H}) ; 7.89(\mathrm{t}$, $1 \mathrm{H}) ; 7.87(\mathrm{~d}, 1 \mathrm{H}) ; 7.61(\mathrm{~d}, 1 \mathrm{H}) ; 7.59(\mathrm{~d}, \mathrm{IH}) ; 6.69(\mathrm{t}, \mathrm{IH})$; $6.67(\mathrm{t}, \mathrm{IH})$.

Anal. Calcd. for $\mathrm{C}_{14} \mathrm{H}_{11} \mathrm{NO}_{3}: \mathrm{C}, 69.70 ; \mathrm{H}, 4.56 ; \mathrm{N}$, 5.80. Found: C, 69.24; H 4.66; N, 5.78.

4-(2-hydroxybenzylideneamino) benzoic acid (3). Yellow solid, yield $72 \%, \mathrm{mp}:>220^{\circ} \mathrm{C}$ decomp, IR $(\mathrm{KBr})$ $v / \mathrm{cm}^{-1}: 3410,3055,1622,1679,1573,1451,930-678$. ${ }^{1} \mathrm{H}$ NMR $\left(\delta\right.$ DMSO-d $\left.\mathrm{d}_{6}\right): 12.70(\mathrm{~s}, 1 \mathrm{H}, \mathrm{OHC}=\mathrm{O}), 8.99(\mathrm{~s}$, $1 \mathrm{H}, \mathrm{HC}=\mathrm{N}), 8.01(\mathrm{dd}, 2 \mathrm{H}) ; 7.70(\mathrm{dd}, 2 \mathrm{H}) ; 7.49(\mathrm{~d}, 1 \mathrm{H})$; $7.44(\mathrm{t}, 1 \mathrm{H}) ; 6.99(\mathrm{t}, 1 \mathrm{H}) ; 6.97(\mathrm{~d}, 1 \mathrm{H})$.

Anal. Calcd. for $\mathrm{C}_{14} \mathrm{H}_{11} \mathrm{NO}_{3}: \mathrm{C}, 69.70 ; \mathrm{H}, 4.56 ; \mathrm{N}$, 5.80. Found: C, 69.28; H 4.64; N, 5.80.

\subsection{Biological Activity}

The synthesized compounds $\mathbf{1}$ - $\mathbf{3}$ were screened for antibacterial activity against Gram positive bacteria strains (Enterococcus feacalis ATCC 29212 and Staphylococcus aureus ATCC 25923) and Gram negative bacteria strains
(Escherichia coli ATCC 25922 and Pseudomonas aeruginosa by agar dilution method [7]. The compounds were dissolved in DMF and dioxane respectively with the solvents used as control. Series of agar plates containing different concentrations of antimicrobial agents $(25,12.5$, $6.25,3.125$ and $1.56 \mathrm{mg} / \mathrm{ml}$ ) were used to determine the susceptibility of the organisms. The different concentrations were added to the agar plates before solidifying. After the plates are set they were dried at $37^{\circ} \mathrm{C}$ with their lids tipped for 20 to 30 minutes in an incubator. The test plates were then inoculated with $1 \mathrm{ml}$ of the test inoculum. The inoculum was diluted to contain $10^{5}$ organisms per $\mathrm{ml}$. The plates were inverted and incubated for $24 \mathrm{~h}$ at $37^{\circ} \mathrm{C}$. The control and tests plates were examined for growth and minimum inhibitory concentration (MIC) value was then established.

\section{RESULTS AND DISCUSSION}

\subsection{Synthesis}

The Schiff bases $\mathbf{1}$ - $\mathbf{3}$ were prepared by the condensation reaction of salicyaldehyde with the corresponding aminobenzoic acid as illustrated in Scheme 1 below. The salicyalidimineaminobenzoic acids $\mathbf{1}$ - $\mathbf{3}$ differed only in the position of the carboxylic functional group on the amine ring. The compounds are soluble in organic solvents such as ethanol, chloroform, DMF, DMSO and dioxane but insoluble in hexane and toluene.

The physical and analytical data are presented in Table 1. The low yield reported for ortho substituted compound, $\mathbf{1}$, is attributed to steric hindrance resulting from close proximity of the aldehyde and carboxylic acid functional groups. Important IR and ${ }^{1} \mathrm{HNMR}$ peaks for the compounds are listed in Table 2.

The Infrared spectra of the all the compounds is composed of a band in the region $1599-1622 \mathrm{~cm}^{-1}$ attributed to $v(\mathrm{C}=\mathrm{N})$ of the azomethine group at 1618,1599 $\mathrm{cm}^{-1}$ and $1622 \mathrm{~cm}^{-1}$ respectively. The lower frequency of this band compared to that of normal $\mathrm{C}=\mathrm{N}(1680-1650$ $\mathrm{cm}^{-1}$ ) may be due to intramolecular interaction between the imine nitrogen and the hydrogen atom which results in a lengthening of the $\mathrm{C}=\mathrm{N}$ bond [8-10]. Furthermore,

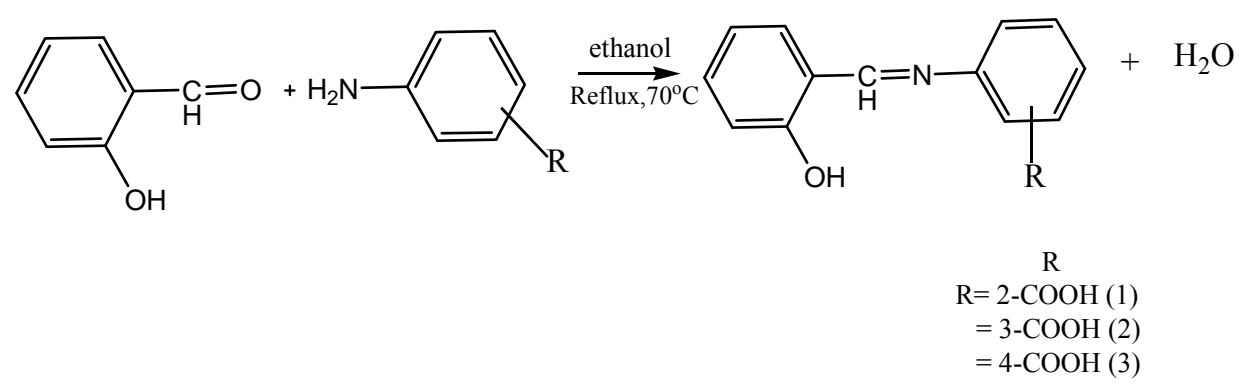

Scheme 1. Synthetic route to compounds 1 - 3 . 
Table 1. Physical properties and analytical data of Schiff bases.

\begin{tabular}{|c|c|c|c|c|c|c|c|c|}
\hline \multirow{2}{*}{ Compound } & \multirow{2}{*}{ Empirical formula } & \multirow{2}{*}{ Formula weight } & \multirow{2}{*}{ Yield \% } & \multirow{2}{*}{ Color } & \multirow{2}{*}{ M.pt } & \multicolumn{3}{|c|}{ Microanalysis (calcd) } \\
\hline & & & & & & $\% \mathrm{C}$ & $\% \mathrm{H}$ & $\% \mathrm{~N}$ \\
\hline 1 & $\mathrm{C}_{14} \mathrm{H}_{11} \mathrm{NO}_{3}$ & 241.24 & 52 & Orange & $198-199$ & $\begin{array}{c}69.23 \\
(69.70)\end{array}$ & $\begin{array}{c}4.53 \\
(4.56)\end{array}$ & $\begin{array}{l}5.77 \\
(5.80)\end{array}$ \\
\hline 2 & $\mathrm{C}_{14} \mathrm{H}_{11} \mathrm{NO}_{3}$ & 241.24 & 86 & Yellow & $183-184$ & $\begin{array}{c}69.24 \\
(69.70)\end{array}$ & $\begin{array}{l}4.66 \\
(4.56)\end{array}$ & $\begin{array}{r}5.78 \\
(5.80)\end{array}$ \\
\hline 3 & $\mathrm{C}_{14} \mathrm{H}_{11} \mathrm{NO}_{3}$ & 241.24 & 72 & Yellow & $>220$ & $\begin{array}{c}69.28 \\
(69.70)\end{array}$ & $\begin{array}{r}4.64 \\
(4.56)\end{array}$ & $\begin{array}{r}5.80 \\
(5.80)\end{array}$ \\
\hline
\end{tabular}

Table 2. Important IR and ${ }^{1}$ HNMR data of Schiff bases.

\begin{tabular}{ccccccccc}
\hline \multicolumn{7}{c}{$\delta(\mathrm{ppm})$} \\
\hline Compd & $v(\mathrm{O}-\mathrm{H})_{\mathrm{Ar}}$ & $v(\mathrm{O}-\mathrm{H})_{\text {acid }}$ & $v(\mathrm{C}=\mathrm{O})$ & $v(\mathrm{C}=\mathrm{N})$ & $v(\mathrm{COO})_{\text {asy }}$ & $v(\mathrm{COO})_{\text {sym }}$ & $\mathrm{C}=\mathrm{N}$ & $\mathrm{OHC}=\mathrm{O}$ \\
1 & 3440 & 3050 & 1682 & 1618 & 1567 & 1459 & 8.95 & 13.06 \\
2 & 3408 & 3057 & 1679 & 1599 & 1568 & 1493 & 9.00 & 12.84 \\
3 & 3410 & 3050 & 1679 & 1622 & 1573 & 1451 & 8.99 & 12.70 \\
\hline
\end{tabular}

2 containing the carboxylic acid group in the meta position shows maximum deviation suggesting that the $\mathrm{COOH}$ group in these compounds behaves as a meta director. The proton NMR of all the Schiff bases showed a singlet at $8.95-9.00 \mathrm{ppm}$ thus confirming the presence of the azomethine proton.

\subsection{Electronic Absorption Spectra}

The absorption spectra of Schiff bases $\mathbf{1}$ - $\mathbf{3}$ was investigated in three solvents of different polarites namely 1,4-dioxane, N,N"-dimethylformamide (DMF) and acetonitrile and the results summarized in Table 3. The use of non H-bonding solvents allows a study of solvent effect on the shift in absorption maxima for the enolimine tautomer with minimum interference from the keto-anime tautomer.

The spectra comprise of absorption bands in the 200 $500 \mathrm{~nm}$ region. The first one or two bands located in wavelength range $210-280 \mathrm{~nm}$ in the spectra of all Schiff bases can be assigned to the excitation of the $\pi$ electrons of the aromatic system [11]. The band in the $330-360 \mathrm{~nm}$ region is due to transition intramolecular charge transfer involving the whole molecule. This band observed in salicylaldimine compounds is facilitated by the presence of intramolecular hydrogen bonding between the hydroxyl group and the azomethine nitrogen [12]. In addition 1 showed band in the region 438 - 520 $\mathrm{nm}$. This is probably due to conjugation between the ortho- $\mathrm{COOH}$ group and the imine functional group which results in cyclization.
Spectra data are good evidence for the presence of solute-solvent interactions between the active solvent and Schiff bases. Difference in position of the carboxylic group in these compounds is reflected in the interaction within the molecules. Substitution of the carboxylic group in the compounds results in an inductive effect of the order para $<$ meta $<$ ortho [13]. Based on this trend, the absorption maxima $\left(\lambda_{\max }\right)$ of the compounds is expected to be in the order $o<m<p$. This is observed in the non-polar solvent dioxane. The absorption spectra are influenced by the physical properties of the solvent. It is observed that acetonitrile gives better resolution of the spectrum for all compounds and both the low and medium energy $\pi-\pi^{*}$ bands are clearly observed. This may be due to the lower hydrogen bonding ability of this dipolar aprotic solvent.

The low energy $\pi-\pi$ band of 2 containing the meta-substituent appears to be insensitive to solvent polarity. This is consistent with earlier reports that indicate that this highly intense $\pi-\pi$ band is sensitive to substitution in the aromatic part of the molecule and is little influenced by changing solvent polarity [14]. However, for $\mathbf{1}$ and $\mathbf{3}$ the band is solvent dependent with the more polar solvent, DMF having highest value of $\lambda_{\text {max }}$. This suggests that the mesomeric effect of the ortho and para groups stabilizes the excited state more than the ground state thereby giving rise to a red shift in absorption maxima in the polar solvent. Red shift in $\lambda_{\max }$ value is observed in the following order: dioxane < acetonitrile $>$ DMF.

The charge transfer band is more sensitive to solvent 
changes. The CT band exhibits a shift of the $\lambda_{\max }$ of CT band to longer wavelength in more polar DMF. Thus, indicating better stabilization of the polar excited state of the compounds in the more polar solvent The change parallels the refractive indices of the solvents with acetonitrile $<$ dioxane $<$ DMF.

\subsection{Antibacterial Activity}

Schiff bases 1 - $\mathbf{3}$ were screened for their in vitro antimicrobial activity against bacteria pathogens $S$. aureus, $E$. coli, E. feacalis and P. aeruginosa using agar dilution technique in DMF and dioxane. The results and MIC values are reported in Table 4 . The minimum inhibitory concentration gives approximation to the least concentration of an antimicrobial needed to prevent microbial growth.

Antimicrobial activity depends on the nature of bacterial strain, the solvent and chelating ability of the Schiff base. It is believed that Schiff bases act by forming a chelate with the bacterial strain. This may involve hydrogen bonding through the azomethine group with the active centres of cell constituents thus resulting in an interference with normal cell process [15]. Hence, the better the hydrogen bonding ability, the more active the compound.

The morphology of the cell wall is a key factor that influences the activity of antibacterial agents. E. feacalis and S. aureus has the highest MIC values of $25 \mathrm{mg} / \mathrm{ml}$ and $12.5 \mathrm{mg} / \mathrm{ml}$ respectively in all the compounds tested. For these strains, the activity is independent on position of substituent, interference of compounds with bacterial cell wall and solvent used.

In this study, Gram positive bacteria gave higher MIC values compared to gram negative bacteria tested. This may be due to the nature of the bacteria cell wall composed of peptidoglycan which is thicker in gram positive bacteria and this usually poses a barrier to the degree of diffusion of antibacterial agents into the enzyme. The thinner cell wall of the gram negative bacteria leads to easier penetration/diffusion of the compound across the cell wall thereby giving better screening effect.

Gram negative strains were more sensitive to solvent variation. The lowest MIC values were reported in dioxane against $P$. aeruginosa for $\mathbf{1}$ and $\mathbf{2}$ and E. coli for $\mathbf{3}$. The effect of solvent on inhibitory activity is pronounced in 3 with MIC values of $12.5 \mathrm{mg} / \mathrm{ml}$ in DMF and 3.125 $\mathrm{mg} / \mathrm{ml}$ in dioxane when screened against $E$. coli. Thus, use of non-polar dioxane medium showed better inhibittion with widely varying effects.

It can be deduced that the different response of the studied Schiff bases arises because of their structural difference and are also solvent dependent.

\section{CONCLUSION}

We have synthesized and characterized a series of Schiff bases of salicyaldehyde and isomeric aminobenzoic acids. The activity data suggest that the antibacterial activity is dependent on the molecular structure of the compound and solvent used. The non-polar solvent exhibits a better screening activity. The compounds possesing broad spectrum of in-vitro antimicrobial activity hence can be used for treatment of some common diseases caused by these pathogens such as septicemia. Furthermore, the higher activity reported for gram negative bacteria suggests that

Table 3. Electronic absorption bands of Schiff bases $1-3$.

\begin{tabular}{|c|c|c|c|c|c|c|}
\hline Schiff base & Solvent & D & Band A & Band B & Band C & Band D \\
\hline & & & $\lambda_{\max }$ & $\lambda_{\max }$ & $\lambda_{\max }$ & $\lambda_{\max }$ \\
\hline \multirow[t]{3}{*}{1} & Dioxane & 2.2 & 252 & 302 & 334 & 438 \\
\hline & Acetonitrile & 37.5 & & 293 & 343 & 497 \\
\hline & DMF & 36.7 & & 303 & 346 & 520 \\
\hline \multirow[t]{3}{*}{2} & Dioxane & & 244 & 319 & 338 & \\
\hline & Acetonitrile & & 220 & 268 & 339 & \\
\hline & $\mathrm{DMF}$ & & & & 360 & \\
\hline \multirow[t]{3}{*}{3} & Dioxane & & 252 & 323 & 343 & \\
\hline & Acetonitrile & & 274 & 320 & 344 & \\
\hline & DMF & & & 324 & 342 & \\
\hline
\end{tabular}

$\mathrm{D}=$ dielectric constant.

Table 4. Minimum inhibitory concentration values of compounds 1 - 3 by dilution method.

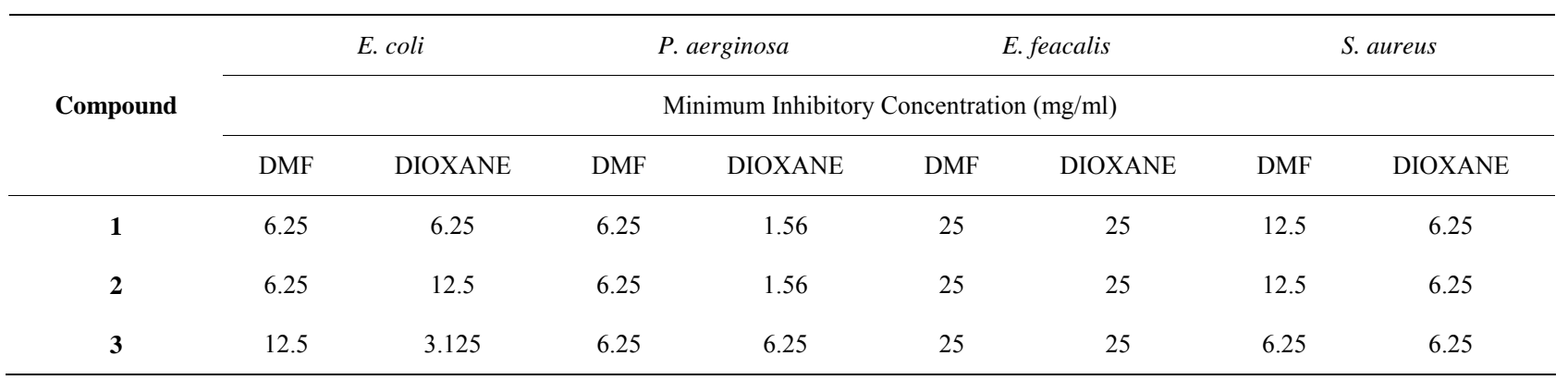


these compounds may also have possible antitumor effects since gram negative bacteria are considered a quantitative microbial method for testing beneficial and important drug candidates.

\section{ACKNOWLEDGEMENTS}

The authors are grateful to Department of Medical Microbiology, University of Lagos where the standard organisms were obtained.

\section{REFERENCES}

[1] Dhar, D.N. and Taploo, C.L. (1982) Schiff bases and their applications. Journal of Scientific \& Industrial Research, 41, 501-506.

[2] Przybylski, P., Huczynski, A., Pyta, K., Brzezinski, B. and Bartl, F. (2009) Biological properties of Schiff bases and azo derivatives of phenol. Current Organic Chemistry, 13, 124-148. http://dx.doi.org/10.2174/138527209787193774

[3] Fasina, T.M., Ogundele, O., Ejiah, F.N. and Dueke-Eze, C.U. (2012) Biological Activity of copper(II), cobalt(II), and nickel(II) complexes of Schiff base derived from ophenylenediamine and 5-bromosalicylaldehyde. International Journal of Biological Chemistry, 6, 24-30. http://dx.doi.org/10.3923/ijbc.2012.24.30

[4] da Silva, C.M., da Silva, D.L., Modolo, L.V., Alves, R.B., de Resende, M.A., Martins, C.V.B. and de Fatima, A. (2011) Schiff bases: A short review of their antimicrobial activities. Journal of Advanced Research, 2, 1-8. http://dx.doi.org/10.1016/j.jare.2010.05.004

[5] Prisakar, V.I., Tsapkov, V.I., Buracheeva, S.A., Byrke, M.S. and Gulya, A.P. (2005) Synthesis and antimicrobial activity of coordination compounds of copper with substituted salicylaldehyde thiosemicarbazones. Pharmaceutical Chemistry Journal, 39, 313-315. http://dx.doi.org/10.1007/s11094-005-0142-8

[6] Przybylski, P., Huczynski, A., Pyta, K., Brzezinski, B. and Bartl, F. (2009) Biological properties of Schiff bases and azo derivatives of phenol. Current Organic Chemistry, 13, 124-148. http://dx.doi.org/10.2174/138527209787193774

[7] Andrews, J.M. (2001) Determination of minimun inhibittory concentrations. Journal of Antimicrobial Chemotherapy, 48, 5-16. http://dx.doi.org/10.1093/jac/48.suppl 1.5

[8] Abdullah, H.K. (2011) FT-IR and UV/Vis spectroscopic study of some Schiff bases derived from aminobenzoic acid and bromobenzaldehyde. Journal of Chemistry, 2, $1-5$.

[9] Aliyu, H.N. and Ado, I. (2009) Spectroscopic and potentiometric investigations of copper(II) complexes with Schiff base derived from 2-aminobenzoic acid and Salicylaldehyde. Bioscience Research Communications, 21, 215-220.

[10] Bennett, J.T., Joshua, C.S., Stephen, J.D., Christopher, M.V., Andreas, D. and Stephen, A.W. (2007) Synthesis, characterization and reactivity of Pd(II) Salicylaldimine complexes derived from aminophenols. Canadian Journal of Chemistry, 85, 392-399. http://dx.doi.org/10.1093/jac/48.suppl_1.5

[11] Soliman, A.A. (1997). Effects of solvents on the electronic absorption spectra of some thioschiff bases. Spectrochimica Acta part A: Molecular and Biomolecular Spectroscopy, 53, 509-515. http://dx.doi.org/10.1016/S1386-1425(96)01823-9

[12] Gabr, A.A. (1990) Spectrophotometric studies on some Schiff bases derived from benzidine. Spectrochimica Acta part A: Molecular Spectroscopy, 46, 1751-1757. http://dx.doi.org/10.1016/0584-8539(90)80247-V

[13] Skyes, P. (1986) A guide to mechanism in Organic Chemistry. 6th Edition, Pearson Education. http://chemistry.ewu.edu/jcorkill/org351/sykes6_e.pdf

[14] Hammud, H.H., Ghannoum, A. and Masoud, M.S. (2006) Spectra regression and correlation coefficients of some benzaldimines and salicylaldimines in different solvents. Spectrochimica Acta A, 63, 255-265. http://dx.doi.org/10.1016/j.saa.2005.04.020

[15] Dharamraj, N., Viswanathanmurthi, P. and Natarajan, K. (2001) Ruthenium (II) complexes containig bidentate Schiff bases and their antifungal activity. Transition Metal Chemistry, 26, 105-109. http://dx.doi.org/10.1023/A:1007132408648 